(Washington, D.C.). There are also offices in Amman, Hong Kong, Moscow, Sarajevo and Vilnius.

The ITUC is a member of the Council of Global Unions, which was created in 2006 as a tool for structured co-operation and co-ordination.

Headquarters: Bd du Roi Albert II, Nº5, bte 1, B-1210 Brussels, Belgium.

Website: http://www.ituc-csi.org

General Secretary: Sharan Burrow (Australia).

President: João Antonio Felicio (Brazil).

\section{International Tribunal for the Law of the Sea (ITLOS)}

The International Tribunal for the Law of the Sea (ITLOS), founded in Oct. 1996 and based in Hamburg, adjudicates on disputes relating to the interpretation and application of the United Nations Convention on the Law of the Sea. The Convention gives the Tribunal jurisdiction to resolve a variety of international law of the sea disputes such as the delimitation of maritime zones, fisheries, navigation and the protection of the marine environment. Its Seabed Disputes Chamber has compulsory jurisdiction to resolve disputes amongst States, the International Seabed Authority, companies and private individuals, arising out of the exploitation of the deep seabed. The Tribunal also has compulsory jurisdiction in certain instances to protect the rights of parties to a dispute or to prevent serious harm to the marine environment, and over the prompt release of arrested vessels and their crews upon the deposit of a security. The Tribunal is composed of 21 judges, elected by signatories from five world regional blocs: five each from Africa and Asia; four from Western Europe and other States; four from Latin America and the Caribbean; and three from Eastern Europe. The judges serve a term of nine years, with one third of the judges' terms expiring every three years.

Headquarters: Am Internationalen Seegerichtshof 1, 22609 Hamburg, Germany.

Website: http://www.itlos.org

Registrar: Philippe Gautier (Belgium).

\section{International Union Against Cancer (UICC)}

Founded in 1933, the UICC is an international non-governmental association of 775 member organizations in 156 countries.

Objectives. The UICC is the only non-governmental organization dedicated exclusively to the global control of cancer. Its objectives are to advance scientific and medical knowledge in research, diagnosis, treatment and prevention of cancer, and to promote all other aspects of the campaign against cancer throughout the world. Particular emphasis is placed on professional and public education.

Membership. The UICC is made up of voluntary cancer leagues, patient organizations, associations and societies as well as cancer research and treatment centres and, in some countries, ministries of health.

Activities. The UICC creates and carries out programmes around the world in collaboration with several hundred volunteer experts, most of whom are professionally active in UICC member organizations. It promotes co-operation between cancer organizations, researchers, scientists, health professionals and cancer experts, with a focus in four key areas: building and enhancing cancer control capacity, tobacco control, populationbased cancer prevention and control, and transfer of cancer knowledge and dissemination. The next UICC World Cancer Congress is scheduled to take place in Paris in Oct.-Nov. 2016.

Address: 62 route de Frontenex, CH-1207 Geneva, Switzerland.

Website: http://www.uicc.org

President: Tezer Kutluk (Turkey).

Chief Executive Officer: Cary Adams (UK).

\section{Inter-Parliamentary Union (IPU)}

Founded in 1889 by William Randal Cremer (UK) and Frédéric Passy (France), the Inter-Parliamentary Union was the first permanent forum for political multilateral negotiations. The Union is a centre for dialogue and parliamentary diplomacy among legislators representing every political system and all the main political leanings in the world. It was instrumental in setting up what is now the Permanent Court of Arbitration in The Hague.

Activities. The IPU fosters contacts, co-ordination and the exchange of experience among parliaments and parliamentarians of all countries; considers questions of international interest and concern, and expresses its views on such issues in order to bring about action by parliaments and parliamentarians; contributes to the defence and promotion of human rights-an essential factor of parliamentary democracy and development; contributes to better knowledge of the working and development of representative institutions and to the strengthening of representative democracy.

Membership. The IPU had 167 members and ten associate members in Feb. 2016.

Headquarters: Chemin du Pommier 5, C.P. 330, CH-1218 Le Grand Saconnex, Geneva 19, Switzerland.

Website: http://www.ipu.org

President: Saber Chowdhury (Bangladesh).

Secretary-General: Martin Chungong (Cameroon).

\section{INTERPOL (International Criminal Police Organization)}

Organization. INTERPOL was founded in 1923, disbanded in 1938 and reconstituted in 1946. The International Criminal Police Organization-INTERPOL was created to ensure and promote the widest possible mutual assistance between all criminal police authorities within the limits of the law existing in the different countries worldwide and the spirit of the Universal Declaration of Human Rights, and to establish and develop all institutions likely to contribute effectively to the prevention and suppression of ordinary law crimes.

Aims. INTERPOL provides a co-ordination centre (General Secretariat) for its 190 member countries. Its priority areas of activity concern criminal organizations, public safety and terrorism, drug-related crimes, financial crime and hightech crime, trafficking in human beings and tracking fugitives 